Al-Manhaj: Jurnal Hukum dan Pranata Sosial Islam

Vol. : : 3 (1), 2021, 35-66

P-ISSN : 2686-1607

E-ISSN : 2686-4819

\title{
FILANTROPI ISLAM SOLUSI ATAS MASALAH KEMISKINAN AKIBAT PANDEMI COVID-19
}

\section{Fitra Rizal, Haniatul Mukaromah}

Institut Agama Islam Negeri Ponorogo

email: fitrajal@gmail.com, haniatulmukaromah93@gmail.com

Abstract: Poverty is one of the macroeconomic problems that is a major concern, especially during the current pandemic. This study aims to describe the solutions offered by Islamic philanthropy (ZISWAF) to the problem of poverty caused by the Covid-19 pandemic. This research uses descriptive qualitative research methodology with content analysis techniques (content analysis) and library research. The results showed that ZISWAF is able to be a solution for the community to the problem of poverty that occurs. Efforts to alleviate poverty that can be done are to manage the funds that have been obtained from ZISWAF properly, with productive management. However, there must be some funds provided to the public that are consumptive in nature. If ZISWAF funds are managed properly and are productive, the hope is that these funds will not run out until whenever they are even able to develop so that their use will be bigger and wider. ZISWAF funds which are consumptive in nature will increase the demand and purchasing power of the community, so that the community will be more prosperous. Meanwhile, productive funds are able to increase investment activities and company productivity (business activities) so that it is able to increase the use of full labor (reduce unemployment) and ultimately improve community welfare so that poverty is reduced. This proves that Islamic philanthropy can be a solution to the problem of poverty.

Keywords: islamic philanthropy, poverty, covid-19 
Abstrak: Kemiskinan merupakan salah satu masalah makroekonomi yang menjadi perhatian utama, khususnya pada masa pandemi saat ini. Penelitian ini bertujuan untuk memamparkan solusi yang ditawarkan oleh filantropi Islam (ZISWAF) atas masalah kemiskinan yang diakibatkan oleh pandemi Covid-19. Penelitian ini menggunakan metodologi penelitian kualitatif deskriptif dengan teknik content analysis (analisis isi) dan riset kepustakaan (library research). Hasil penelitian menunjukkan bahwa ZISWAF mampu menjadi solusi bagi masyarakat atas masalah kemiskinan yang terjadi. Upaya pengentasan kemiskinan yang dapat dilakukan adalah dengan mengelola dana yang telah diperoleh dari ZISWAF dengan baik, dengan pengelolaan yang produktif. Walaupun demikian harus ada sebagain dana yang diberikan kepada masyarakat yang bersifat konsumtif. Dana ZISWAF jika dikelola dengan baik dan bersifat produktif harapanya adalah dana tersebut tidak akan habis sampai kapanpun bahkan mampu berkembang sehingga pemanfaatanya akan semakin besar dan luas. Dana ZISWAF yang bersifat konsumtif akan meningkatkan permintaan dan daya beli masyarkat, sehingga masyarakat semakin sejahtera. Sedangkan dana yang bersifat produktif mampu meningkatkan kegiatan investasi dan produktifitas perusahaan (kegiatan bisnis) sehingga hal tersebut mampu meningkatkan penggunaan tenaga kerja penuh (mengurangi pengangguran) dan pada akhirnya meningkatkan kesejahteraan masyarakat sehingga kemiskinan semakin berkurang. hal tersebut membuktikan bahwa filantropi Islam mampu menjadi solusi atas masalah kemiskinan.

Kata Kunci: filantropi Islam, kemiskinan, covid-19

\section{PENDAHULUAN}

Saat ini dunia mengalami bencana pandemi Corona Virus (Covid-19). Salah satu upaya yang dilakukan untuk mengurangi penyebaran wabah ini adalah dengan social atau physical distancing. Akantetapi hal tersebut berdampak pada penurunan aktivitas ekonomi secara keseluruhan. Physical distancing yang 
Fitra Rizal, Haniatul Mukaromah, Filantropi Islam Solusi Atas Masalah ...

berdampak pada pembatasan aktifitas masyarakat akan mengakibatkan penurunan agregat supply dan agregat demand dalam perekonomian yang berdampak pada penurunan jumlah penawaran dan permintaan. Kondisi masyarakat yang hanya berdiam diri di rumah (stay at home), akan melumpuhkan sektor produksi dan konsumsi masyarakat, jika produksi menurun kemudian diikuti dengan penurunan konsumsi maka yang terjadi adalah perekonomian lumpuh sehingga kesejahteraan masyarkat menurun. ${ }^{1}$ Hal tersebut berdampak pada pengunaan tenaga kerja yang menurun dan daya beli (konsumsi) masyarakat juga menurun sehingga kemiskinan dan pengangguran meningkaat. Kelompok yang paling terdapat secara ekonomi adalah masyarakat menengah ke bawah yang bekerja informal. ${ }^{2}$

Indonesia merupakan satu dari sekian banyak negara yang mengalami keguncangan dalam sektor ekonomi akibat adanya pandemic Covid-19. Menurut Badan Pusat Statistik, pertumbuhan ekonomi Indonesia pada kuartal I tahun 2020 hanya mencapai 2.97\%, capaian ini jauh di bawah proyeksi pemerintah, yaitu sebesar 4.6\%. Dalam kesempatan yang lain bahkan Mohammad Faisal, ${ }^{3}$ memprediksi bahwa pada kuartal II tahun 2020 terjadi kontraksi antara $-1.9 \%$ hingga $-5 \%$. Nilai ini jauh lebih kecil daripada tahun lalu yang jika dilihat dari Badan Pusat Statistik pada kuartal I tahun 2019, Indonesia mencatatkan 5,07\% sehingga

1 Azwar, "Solusi Ekonomi dan Keuangan Islam Saat Pandemi COVID-19," Kementerian Keuangan RI, 2020; Achmad al-Nidzami Baridzi, "Solusi Ekonomi dan Keuangan Islam dalam Menghadapi Pandemi Covid-19," Kompasiana, 2020.

2 Azwar, "Solusi Ekonomi dan Keuangan Islam Saat Pandemi COVID-19."

3 Direktur Eksekutif Center of Reform on Economics. 
terlihat jelas bahwa Indonesia saat ini dihadapkan pada jurang resesi ekonomi. ${ }^{4}$

Pertumbuhan ekonomi Indonesia yang tidak mencapai proyeksi pemerintah pada Kuartal I 2020, mengisyaratkan pada khalayak umum bahwa ancaman pandemi Covid-19 bukan hanya isapan jempol belaka. Penerapan Work From Home (WFH) dan Physical Distancing mengakibatkan adanya perubahan pola ekonomi masyarakat seperti menurunnya angka produksi akibat banyaknya pekerja yang terpaksa dirumahkan, tingkat konsumsi dan belanja masyarakat mulai melemah dikarenakan tingkat pendapatan masyarakat berkurang di saat pandemi terutama mereka yang bekerja sebagai pekerja informal atau pekerja harian. Hal ini jika berlangsung secara terus menerus dalam jangka waktu yang lama akan mengakibatkan peningkatan proyeksi kemiskinan di Indonesia meningkat $12.4 \%$ atau sebanyak 8.5 juta orang akan menjadi miskin. ${ }^{5}$

Kemiskinan merupakan masalah dalam makroekonomi yang selalu menjadi perhatian Negara terutama bagi Negara berkembang. Karena jika pemerintah (negara) tidak mampu menangani masalah ini dengan baik akan berakibat fatal bagi keberlangsungan pemerintah tersebut. Kemiskinan akan menimbulkan persoalan sosial, ekonomi, dan politik di masyarakat

4 Badan Pusat Statistik, "Ekonomi Indonesia Triwulan I 2020 Tumbuh 2,97 Persen," BPS, 2020.

5 Baridzi, "Solusi Ekonomi dan Keuangan Islam dalam Menghadapi Pandemi Covid-19." 
sehingga akan terjadi kekacauan dan ketidak stabilan pemerintah. ${ }^{6}$ Kemiskinan menjadi masalah makro ekonomi yang menakutkan di banyak negara berkembang, termasuk Indonesia. Jika masalah tersebut tidak mampu diatasi dengan baik, maka pada akhinya akan menimbulkan kekacauan politik dan sosial yang sangat serius. Seperti yang terjadi pada tahun 1998, suatu pemerintahan bisa jatuh karena amukan rakyat miskin yang sudah tidak tahan lagi dengan kondisi yang dihadapinya. ${ }^{7}$

Pertumbuhan ekonomi mempunyai tujuan untuk meningkatkan kesempatan kerja masyarakat, meningkatkan upah masyarakat dan mengurangi kemiskinan, sehingga kesejahteraan dan taraf hidup masyarakat akan meningkat. ${ }^{8}$ Jadi kesimpulannya kesejahteraan masyarakat dapat ditingkatkan dengan cara mengurangi kemiskinan, artinya untuk meningkatkan kesejahteraan masyarkat maka tingkat permintaan dan penawaran (agregat supply dan agregat demand) sehingga meningkatkan produksi dan terjadi penggunaan tenaga kerja penuh, banyak masyarakat yang berkeja sehingga menggerser kurva parmintaan kekanan (konsumsi meningkat). Jika agregat supply dan agregat demand meningkat maka perekonomian semakin mambaik dan kesejahteraan masyarkat meningkat secara pasti.

${ }^{6}$ Erwan Agus Purwanto, "Mengkaji Potensi Usaha Kecil dan Menengah untuk Pembuatan Kebijakan Anti Kemiskinan di Indonesia," Jurnal Ilmu Sosial dan Ilmu Politik 10, no. 3 (2007): 296.

7 Tulus T.H. Tambunan, Perekonomian Indonesia Kajian Teoritis dan Analisis Praktis (Bogor: Ghalia Indonesia, 2012), 181.

8 Sadono Sukirno, Makroekonomi: Teori Pengantar (Jakarta: PT. Rajagrafindo Persada, 2011). 
Penduduk miskin adalah masyarakat yang memiliki ratarata pengeluaran perkapita dibawah garis kemiskinan, dikatakan berada di bawah garis kemiskinan apabila pendapatan mereka tidak cukup untuk memenuhi kebutuhan yang paling pokok, seperti: sandang, pangan, papan. ${ }^{9}$ Indonesia sebagai negara dengan jumlah penduduk muslim terbesar di dunia, harus mampu memberikan peran dalam upaya pengentasan kemiskinan dengan menjadikan filantropi Islam sebagai solusi atas masalah kemiskinan yang dihadapi masyarakat khususnya pada masa pandemi saat ini. Berdasarkan hal diatas maka perlu dikaji beberapa isu penting terkait bagaimana solusi yang ditawarkan filantropi Islam tentang konsep pengentasan kemiskinan, sehingga tingkat kemiskinan dapat dikurangi dan pada akhirnya kesejahteraan masyarakat tercapai. Penelitian ini menggunakan pendekatan metodologi penelitian kualitatif deskriptif dengan teknik content analysis dan library research.

\section{FILANTROPI ISLAM}

Kata 'filantropi' (Inggris: philanthropy) merupakan istilah yang tidak dikenal pada masa awal Islam, meskipun belakangan ini sejumlah istilah Arab digunakan sebagai padanannya. Filantropi kadang-kadang disebut al-'ata' al-ijtima'i (pemberian sosial), adakalanya dinamakan al-takaful al-insani (solidaritas kemanusiaan), atau 'ata khayri (pemberian untuk kebaikan).

${ }_{9}^{9}$ Abu Ahmadi, Ilmu Sosial Dasar (Jakarta: PT Renika Cipta, 1991), 326. 
Kadang juga disebut sebagai al-birr (perbuatan baik) atau alsadaqah (sedekah). ${ }^{10}$

Istilah filantropi Islam merupakan istilah yang muncul pada zaman modern (hasil adopsi kata). Berasal dari kata Yunani philanthropia, philo (cinta) dan anthrophos (manusia), filantropi secara umum berarti cinta terhadap, atau sesama, manusia. Mengingat luasnya makna cinta yang terkandung dalam istilah tersebut, filantropi sangat dekat maknanya dengan charity (Latin: caritas) yang juga berarti cinta tak bersyarat (unconditioned love.$^{11}$

Praktik filantropi sesungguhnya telah ada sebelum Islam mengingat wacana keadilan sosial juga telah berkembang. Dalam bahasa Indonesia, istilah yang cukup sepadan dengan filantropi adalah kedermawanan sosial, yang meliputi zakat,infak, sedekah dan wakaf (ZISWAF). ${ }^{12}$ Filantropi Islam adalah kedermawanan sosial yang terprogram dan ditujukan untuk pengentasan masalah sosial (seperti kemiskinan). Filantropi Islam ada yang berorientasi pada pengentasan kemiskinan dalam jangka pendek dan jangka panjang, jangka pendek misalnya memberikan bantuan yang bersifat konsumtif sekali pakai habis. Adapun yang bersifat jangka panjang dengan memberikan bantuan yang bisa dimanfaatkan dalam waktu yang lama untuk meningkatkan pendapatan.

10 Ibrahim Barbara, From Charity to Social Change: Trends in Arab Philanthropy (Cairo: American University in Cairo Press, 2008).

11 Anheier Helmut K and List Regina A, A Dictionary of Civil Society, Philanthropy and the Non-Profit Sector (New York: Routledge, 2005).

12 Abdiansyah Linge, "Filantropi Islam Sebagai Instrumen Keadilan Ekonomi," Jurnal Perspektif Ekonomi Darussalam 1, no. 2 (2015). 
Konsepnya tidak memberikan ikan tetapi memberi kail dan akses serta keadilan untuk memperoleh ekonomi.

ZISWAF adalah bentuk ajaran Islam yang mengajak umat manusia untuk peduli terhadap sesama. Keempat filantropi ini memiliki persamaan yaitu sama-sama bernilai ibadah dan meningkatkan solidaritas sosial. Keempatnya memiliki peran penting dalam pemberdayaan masyarkat yakni dengan pendayagunaan dana filantropi tersebut dapat meminimalisir ketimpangan perekonomian masyarakat, mengentaskan kemiskinan, dan meminimalisir pengangguran sehingga terwujudlah masyarakat yang tentram makmur dan sejahtera.

Semangat dari filantropi Islam adalah menjalankan ibadah yang bersifat sosial dalam bentuk solidaritas sesama manusia, di mana orang yang lebih beruntung membantu mereka yang kurang beruntung. Islam secara inheren memiliki semangat filantropis. Ini dapat ditemukan dalam ayat al-Quran yang menganjurkan bahkan mewajibkan umatnya agar berderma, seperti yang tercantum dalam surah al-Baqarah ayat 215.

Filantropi dalam Islam merupakan suatu konsep kedermawanan sosial yang bertujuan untuk kebaikan. Konsep filantri Islam jika diterapkan dengan baik mampu mengurangi kesenjangan sosial diantara masyarakat, terjadi pemerataan kekayaan dan kemiskinan terkurangi. Efektifitas filantropi dalam upaya mengurangi kesenjangan sosial tidak terlepas dari peran lembaga filantropi yang mengelola kegiatan tersebut, dengan cara memberikan distribusi kekayaan (modal) kepada pihak yang tidak 
mempu, sehingga dapat berperan dalam kegiatan ekonomi, menumbuhkan kegiatan investasi, meningkatkan produksi, meningkatkan pendapatan, mengurangi pengangguran dan kemiskinan, sehingga pada akhirnya kesejahteraan masyarakat tercapai.

\section{ZAKAT, INFAQ, SADAQAH, DAN WAKAF (ZISWAF)}

Zakat menurut bahasa berarti kesuburan, kesucian, barakah dan berarti juga mensucikan. Diberi nama zakat karena dengan harta yang dikeluarkan diharapkan akan mendatangkan kesuburan baik itu dari segi hartanya maupun pahalanya. Selain itu zakat juga merupakat penyucian diri dari dosa dan sifat kikir. ${ }^{13}$ Secara istilah zakat adalah memberikan harta apabila telah mencapai nishab dan haul kepada orang yang berhak menerimanya (mustahiq) dengan syarat tertentu. Nishab adalah ukuran tertentu dari harta yang dimiliki yang wajib dikeluarkan zakatnya, sedangkan haul adalah berjalan genap satu tahun. ${ }^{14}$ Adapun dasar hukum wajib zakat tertera dalam al-Qur'an surat alBaqarah ayat 43 dan surat al-Tawbah ayat 103.

Infaq menurut bahasa berasal dari kata anfaqa yang berarti menafkahkan, membelanjakan, memberikan atau mengeluarkan harta. Menurut istilah fiqh kata infaq mempunyai makna memberikan sebagian harta yang dimiliki kepada orang yang telah disyariatkan oleh agama untuk memberinya seperti orang-orang faqir, miskin, anak yatim, kerabat dan lain-lain. Istilah yang dipakai 24.

${ }^{13}$ Hasbi Ash-Shiddieqy, Pedoman Zakat (Jakarta: Bulan Bintang, 1984), ${ }^{14}$ Rois Mahfud, Al-Islam (Jakarta: Erlangga, 2011), 30. 
dalam al-Qur'an berkenaan dengan infaq meliputi kata: zakat, sadaqah, hadyu, jizyah, hibah dan wakaf. $^{15}$ Jadi semua bentuk perbelanjaan atau pemberian harta kepada hal yang di-syariatkan agama dapat dikatakan infaq, baik itu yang berupa kewajiban seperti zakat atau yang berupa anjuran sunnah seperti wakaf atau sha-daqah. Adapun dalil al-Qur'an yang menunjukkan pada anjuran berinfaq salah satunya terdapat dalam surat al-Baqarah ayat 195:

Sadaqah merupakan pemberian suatu benda oleh seseorang kepada orang lain karena mengharapkan keridhaan dan pahala dari Allah Swt. dan tidak mengharapkan suatu imbalan jasa atau penggantian. Atau dapat pula diartikan memberikan sesuatu dengan maksud untuk mendapatkan pahala. ${ }^{16}$ Pada dasarnya setiap kebajikan itu adalah shadaqah. Dilihat dari pengertian tersebut, shadaqah memiliki pengertian luas, menyangkut hal yang bersifat materi atau non materi. Dalam kehidupan sehari-hari, shadaqah sering disama-kan dengan infaq. Namun mengingat pengertian tadi dapat dibedakan bahwa shadaqah lebih umum daripada infaq, jika infaq berkaitan dengan materi, sedangkan shadaqah materi dan non materi. Contoh shadaqah yang berupa materi seperti memberi uang kepada anak yatim setiap tang-gal sepuluh bulan Muharram, sedangkan yang berupa nonmateri 2012), 17.

${ }^{15}$ Mardani, Fiqih Mu'amalah (Jakarta: Kencana Prenada Media Group,

16 Zuhdi, Studi Islam (Jakarta: PT. Rajagrafindo Persada, 1993), 82. 
seperti tersenyum kepada orang lain. ${ }^{17}$ Adapun dalil al-Qur'an yang menunjukkan tentang anjuran shadaqah seperti yang tercantum dalam surat Yūsuf ayat 88:

Wakaf adalah kata yang berasal dari bahasa Arab yaitu waqf yang berarti menahan, menghentikan atau mengekang. Sedangkan menurut istilah ialah menghentikan perpindahan milik suatu harta yang bermanfaat dan tahan lama sehingga manfaat harta itu dapat digunakan untuk mencari keridhaan Allah Swt. Wakaf juga dapat diartikan pemberian harta yang bersifat permanen untuk kepentingan sosial keagamaan seperti orang yang mewakafkan sebidang tanah untuk dibangun masjid atau untuk di-jadikan pemakaman umum.18 Dasar hukum wakaf terdapat dalam surat Ăli 'Imrān ayat 92. Dalam ayat tersebut terdapat perintah menafkahkan harta yang dicintai, yang dimaksudkan adalah wakaf sebagaimana yang diterangkan oleh hadis Nabi riwayat Bukhari Muslim bahwa setelah diturunkan ayat ini, Thalhah salah seorang Sahabat Nabi dari golongan Anshar yang terkaya di Madinah mewakafkan kebun kurma yang paling disenanginya. ${ }^{19}$

Dari penjelasan di atas, dapat disimpulkan bahwa perbedaan dari keempat filantropi Islam tersebut adalah; (1) Shadaqah merupakan istilah yang paling umum sehingga infaq, wakaf dan zakat dapat dikategorikan sebagai shadaqah. (2) Zakat

17 Qurratul Uyun, "Zakat, Infaq, Shadaqah, dan Wakaf Sebagai Konfigurasi Filantropi Islam," Jurnal Islamuna 2, no. 2 (2015), 221.

18 Uyun, 22.

19 Fitra Rizal, "Wakaf Non Muslim dan Wakaf Uang Menurut Pandangan Wahbah Zuhaili," Al-Intaj: Jurnal Ekonomi Dan Perbankan Syariah 5, no. 2 (September 9, 2019): 176, https://doi.org/10.29300/aij.v5i2.2059. 
terikat oleh waktu dan nishab, sedangkan infaq, shadaqah dan wakaf dapat dilakukan kapan saja. (3) Zakat diperuntukkan bagi golongan tertentu, sedangkan infaq dan shadaqah diberikan kepada siapa saja. (4) Zakat merupakan kewajiban, sedangkan wakaf, infaq dan shadaqah sebagai amalan sunnah yang dianjurkan (baik jika dikerjakan). Sedangkan persamaannya adalah; (1) sama-sama sebagai upaya untuk meningkatkan ketaqwaan atau bertujuan untuk mendapatkan ridha Allah Swt. (2) Sama-sama merupakan ibadah yang diperintah-kan dan mendapatkan pahala dari Allah Swt sebagai balasannya. (3) Samasama memiliki nilai positif baik bagi pelaku ataupun penerima.

\section{MAKNA KEMISKINAN}

Kemiskinan memiliki konsep yang beragam, Badan Pusat Statistik (BPS) mendefinisikan kemiskinan didasarkan pada garis kemiskinan. Nilai garis kemiskinan tersebut mengacu pada kebutuhan minimum makanan yang disetarakan dengan 2.100 kilokalori perkapita perhari, ditambah dengan kebutuhan minimurn non-makan yang meliputi: perumahan, sandang, pendidikan dan kesehatan. ${ }^{20}$

Menurut BPS, Penduduk Miskin adalah penduduk yang memiliki rata- rata pengeluaran perkapita dibawah garis kemiskinan, yaitu masyarakat yang berpenghasilan di bawah $\mathrm{Rp}$ 
7.057 per hari. ${ }^{21}$ Sedangkan Bank Dunia mengukur garis kemiskinan berdasarkan pada pendapatan seseorang kurang dari USD 2 per hari.22 Mereka dikatakan berada di bawah garis kemiskinan karena pendapatan mereka tidak cukup untuk memenuhi kebutuhan hidup yang paling pokok, seperti: sandang, pangan, papan. ${ }^{23}$ Secara umum Kemiskinan merupakan ketidakmampuan seseorang atau sekelompok untuk mencukupi kebutuhan pokok minimum yang menyebabkan ketidaknyamanan dalam hidup. Dalam pandangan Islam, kemiskinan adalah problem yang perlu diselesaikan, bahkan merupakan suatu krisis yang berbahaya sehingga harus segera ditanggulangi dan diobati. Islam menegaskan, penanggulangan kemiskinan merupakan suatu hal yang patut dilakukan dan tidak bertentangan dengan takdir Ilahi. ${ }^{24}$

\section{INDIKATOR KEMISKINAN}

Garis kemiskinan adalah suatu ukuran yang menyatakan besarnya pengeluaran untuk memenuhi kebutuhan dasar minimum makanan dan kebutuhan non makanan. Garis kemiskinan yang digunakan setiap negara berbeda-beda, sehingga tidak ada satu garis kemiskinan yang berlaku umum. Hal ini disebabkan karena adanya perbedaan lokasi dan standar kebutuhan hidup. Adapun ukuran yang digunakan untuk

21 Badan Pusat Statistik.

22 The World Bank, Making the New Indonesia Work for the Poor (Washigton, DC: The World Bank, 2006), 31.

${ }^{23}$ Ahmadi, Ilmu Sosial Dasar.

24 Muhammad Yusuf Al-Qordowi, Konsepsi Islam dalam Mengentaskan Kemiskinan, Ter. Umar Fanany (PT. Bina Ilmu Ofset: PT.Bina Ilmu Ofset, 1996), 49. 
mengetahui tingkat kemiskinan secara adalah dengan mengetahui tingkat pendapatan dan kebutuhan relatif. ${ }^{25}$

Indikator-indikator kemiskinan sebagaimana yang di kutip dari Badan Pusat Statistik, antara lain sebagi berikut; (1) Ketidakmampuan memenuhi kebutuhan konsumsi dasar (sandang, pangan dan papan), (2) Tidak adanya akses terhadap kebutuhan hidup dasar lainnya (kesehatan, pendidikan, sanitasi, air bersih dan transportasi), (3) Tidak adanya jaminan masa depan (karena tiadanya investasi untuk pendidikan dan keluarga), Kerentanan terhadap goncangan yang bersifat individual maupun massa, (5) Rendahnya kualitas sumber daya manusia dan terbatasnya sumber daya alam, (6) Kurangnya apresiasi dalam kegiatan sosial masyarakat, (7) Tidak adanya akses dalam lapangan kerja dan mata pencaharian yang berkesinambungan. ${ }^{26}$

Dalam konsep fiqih, untuk merumuskan kemiskinan harus mengethui konsep kebutuhan minimum, kecukupan minimum dan kesenangan minimum. Menurut Al-Ghazali, kesejahteraan masyarakat tergantung pada pencarian dan pemeliharaan lima tujuan dasar, yaitu: melindungi agama, hidup atau jiwa, intelektual atau akal, keluarga atau keturunan dan harta atau kekayaan. ${ }^{27}$ Maka ketika masyarakat dapat memenuhi kebutuhan dasar tersebut berarti mereka telah mencapai kesejahteraan dan bebas dari kemiskinan. Berikut ini beberapa ciri yang melekat pada

25 Ahmadi, Ilmu Sosial Dasar, 327.

26 Badan Pusat Statistik, "Kemiskinan dan Ketimpangan."

27 Ririn Tri Puspita Ningrum, Kemiskinan dalam Bingkai Islam KeIndonesiaan (Yogyakarta: Interpena, 2013). 
penduduk miskin antara lain; (1) Pendapatan masih rendah atau tidak berpendapatan, (2) Tidak memiliki pekerjaan tetap, (3) Pendidikan rendah bahkan tidak berpendidikan, (4) Tidak memiliki tempat tinggal, (5) Tidak terpenuhinya standar gizi minimal. ${ }^{28}$

\section{PENYEBAB KEMISINAN}

Tingkat kemiskinan disuatu Negara tergantung pada dua faktor utama, yaitu: tingkat pendapatan nasional dan tingkat kesenjangan dalam distribusi pendapatan. ${ }^{29}$ Menurut Sharp penyebab kemiskinan dipandang dari sisi ekonomi adalah (1) Secara mikro, kemiskinan muncul karena adanya ketidaksamaan pola kepemilikan sumberdaya yang menimbulkan distribusi pendapatan yang timpang, (2) Kemiskinan muncul akibat perbedaan dalam kualitas sumberdaya manusia. Kualitas sumberdaya manusia yang rendah berarti produktifitasnya rendah, yang pada gilirannya upahnya rendah, (3) Kemiskinan muncul akibat perbedaan akses dalam modal. ${ }^{30}$

Sementara itu penyebab kemiskinan secara umum dibedakan menjadi dua faktor yaitu (1) Faktor eksogen (faktor yang berada di luar individu tersebut) dibedakan menjadi faktor alamiah (keadaan alam, iklim, dan bencana alam) dan faktor

28 Tri Wahyu Rejekiningsih, "Identifikasi Faktor Penyebab Kemiskinan di Kota Semarang dari Dimensi Kultural," Jurnal Ekonomi Pembanguna 12, no. 1 (2011): 34 .

${ }^{29}$ Micheal P. Todoro, Pembangunan Ekonomi di Dunia Ketiga, Ter. Haris Munandar (Jakarta: PT. Gelora Aksara Pratama, 1998), 51.

30 Mudrajad Kuncoro, Ekonomi Pembangunan Teori, Masalah dan Kebijakan (Yogyakarta: UPP-AMP YKPN, 1997). 
buatan atau struktur (kolonialisme, sifat pemerintahan, sistem ekonomi dan sebagainya), (2) faktor endogen (faktor yang berasal dari dalam individu itu sendiri) misalnya sifat malas, boros dan lain sebagainya. ${ }^{31}$

Faktor-faktor yang mempengaruhi kemiskinan antara lain: pertumbuhan pendapatan, tingkat pendidikan, tenaga kerja dan struktur ekonomi. ${ }^{32}$ Dengan meningkatkan dan mengoptimalakan faktor-faktor tersebut diharapkan kemiskinan akan semakin terkurangi. Kemiskinan menurut Islam suatu kondisi yang harus diberantas dan masyarakat miskin harus diberdayakan.

Tidak dapat dipungkiri, kemiskinan dapat berdampak negatif bagi kehidupan masyarakat, bangsa dan agama. Adapun bahaya dari kemiskinan adalah sebagai berikut; ${ }^{33}$ Bahaya Kemiskinan Terhadap Akidah (Agama). Dengan kondisi miskin dengan pendapatan yang tidak menentu, sementara kebutuhan hidup semakin meningkat, dan disaat yang bersamaan tidak ada orang kaya yang mau mengulurkan bantuannya, maka orang miskin tersebut dapat berfikir salah tentang Allah. Ia dapat saja merasakan ketidakadilan dari Allah. Bahaya kemiskinan terhadap moral. Orang miskin dapat saja bertindak criminal, karena hidup ditengah-tengah orang kaya yang sombong. Kekecewaan dan

${ }^{31}$ Koentjaraningrat, Kebudayaan, Mentalitet dan Pembangunan (Jakarta: Gramedia, 1983).

32 Tambunan, Perekonomian Indonesia Kajian Teoritis dan Analisis Praktis, 185.

${ }^{33}$ Muhammad Ridwan, Manajemen Baitul Maal Wa Tanwil (Yogyakarta: UII Press, 2011), 21. 
keputusasaan dapat mengalahkan nuraninya sehingga mengabaikan nilai-nilai moral dan akhlak.

\section{VIRUS CORONA (COVID-19)}

Virus Corona adalah sekumpulan virus dari subfamili Orthocronavirinae dalam keluarga Coronaviridae dan ordo Nidovirales. Kelompok virus ini yang dapat menyebabkan penyakit pada burung dan mamalia, termasuk manusia. Pada manusia, coronavirus menyebabkan infeksi saluran pernapasan yang umumnya ringan, seperti pilek, meskipun beberapa bentuk penyakit seperti; SARS, MERS, dan COVID-19 sifatnya lebih mematikan.

Dalam kondisi saat ini, virus corona bukanlah suatu wabah yang bisa diabaikan begitu saja. Jika dilihat dari gejalanya, orang awam akan mengiranya hanya sebatas influenza biasa, tetapi bagi analisis kedokteran virus ini cukup berbahaya dan mematikan. Tahun 2020 merupakan tahun yang mengkhawatirkan seluruh negara, tanpa terkecuali negara Indonesia. Hal itu disebabkan munculkan wabah virus Corona, yang bermula dari Kota Wuhan China, dan menyebar ke seluruh penjuru dunia. Juru bicara pemerintah untuk penanganan virus corona, Achmad Yurianto secara resmi informasi perkembangan kasus Covid-19 bahwa sampai dengan hari Kamis, 19 Maret 2020 penelitian yang dilakukan oleh WHO dengan menghimpun semua ahli virus corona di dunia masih belum mendapatkan suatu kesepakatan yang bisa 
dijadikan standar dunia terkait dengan spesimen pengobatan yang definitif terhadap Covid-19.34

Terkait perkembangan virus corona tersebut, akhirnya pemerintah membuat kebijakan sebagai langkah pertama yaitu berupa anjuran social distancing. Ini dimaknai bahwa pemerintah menyadari sepenuhnya penularan dari covid-19 ini bersifat droplet percikan lendir kecil-kecil dari dinding saluran pernapasan seseorang yang sakit yang keluar pada saat batuk dan bersin. Oleh karena itu, pemerintah menganjurkan kepada siapapun yang batuk dan yang menderita penyakit influenza untuk menggunakan masker, tujuannya untuk membatasi percikan droplet dari yang bersangkutan. Selain mengatur jarak antar orang, agar kemungkinan peluang tertular penyakit bisa menjadi lebih rendah. Implikasinya bahwa pertemuan-pertemuan dengan jumlah yang besar dan yang memungkinkan terjadinya penumpukan orang harus dihindari.

Maka dari itu sangat penting untuk disadari bersama dari seluruh komponen masyarakat untuk tidak melaksanakan kegiatan yang mengerahkan banyak orang dalam satu tempat yang tidak terlalu luas dan menyebabkan kerumunan. Hal ini dianggap sebagai salah satu upaya yang sangat efektif untuk mengurangi sebaran virus. Oleh karena itu, social distancing harus diimplementasikan, baik dalam kehidupan sehari-hari, di lingkungan kerja ataupun di lingkungan rumah tangga. Selain tetap

34 Andhika Prasetia, "Prediksi Pemerintah Pasien Corona Akan Bertambah," DetikNews, 2020. 
melakukan pencegahan melalui upaya pola hidup bersih dan sehat dengan selalu mencuci tangan menggunakan sabun dengan air yang mengalir. ${ }^{35}$ Untuk mengantisipasi dan mengurangi jumlah penderita virus corona dengan memberikan kebijakan membatasi aktifitas keluar rumah, kegiatan sekolah dirumahkan, bekerja dari rumah (work from home), bahkan kegiatan beribadah pun dirumahkan. Hal ini sudah menjadi kebijakan pemerintah berdasarkan pertimbangan-pertimbangan yang sudah dianalisa dengan maksimal tentunya.

\section{DAMPAK VIRUS CORONA TERHADAP EKONOMI KEMISNINAN}

Presiden Joko Widodo telah menetapkan pandemi Covid-19 sebagai bencana nasional. Pandemi ini pun berdampak cukup signfikan terhadap perekonomian Indonesia. Bahkan Menteri Keuangan Sri Mulyani Indrawati mengatakan, dalam situasi yang sangat berat, akan terjadi peningkatan jumlah angka kemiskinan hingga 3,78 juta orang, di dalam skenario perekonomian akibat pandemi virus corona yang telah disusun pemerintah, pertumbuhan ekonomi yang tadinya ditargetkan tumbuh di kisaran 5,3 persen tahun ini diproyeksi hanya akan tumbuh ke 2,3 persen. Bahkan bila pandemi ini tidak segera diatasi, pertumbuhan ekonomi sepanjang tahun 2020 akan tumbuh negatif 0,4 persen. Berdasarkan hal tersebut maka corona akan menekan kondisi perekonomina dan memberikan dampak sosial khususnya kemiskinan. Angka kemiskinan bisa meningkat hingga

35 Nur Rohim Yunus and Annissa Rezki, "Kebijakan Pemberlakuan Lockdown Sebagai Antisipasi Penyebaran Corona Virus Covid-19," SALAM; Jurnal Sosial \& Budaya Syar-I 7, no. 3 (2020): 230. 
1,1 juta orang untuk skenario berat. Sementara untuk skenario yang lebih berat, tambahan angka kemiskinan akan sebanyak 3,78 juta orang. ${ }^{36}$

Badan Pusat Statistik (BPS) menggelar Survei Sosial Demografi Dampak Covid-19. Survei yang diunggah ke bps.go.id pada 1 Juni 2020 ini menggunakan metode NonProbability Sampling yang merupakan kombinasi dari Convenience, Voluntary dan Snowball Sampling dengan total 87.379 responden. Hasil survei menunjukkan bahwa 2,52 persen responden mengaku terkena PHK akibat perusahaan mereka terimbas Covid-19. Sementara, 18,34 persen dirumahkan. Jika berdasarkan jenis kelamin, pekerja laki-laki yang mengaku kena PHK mencapai 3,18 persen dari total responden laki-laki. Sementara, 1,87 persen dari responden perempuan juga mengaku jadi korban PHK. ${ }^{37}$

Dampak lain yang turut dibahas dalam survei ini adalah dampak wabah corona terhadap pendapatan masyarakat. Dalam hal ini, 63,16 persen karyawan yang dirumahkan mengalami penurunan pendapatan. Sementara, 36,84 persen responden yang masih bekerja mengaku juga mengalami penurunan pendapatan. Adapun berdasarkan kelompok pendapatan, virus corona paling berdampak pada masyarakat dengan pendapatan rendah. Dari total responden berpendapatan normal kurang dari Rp 1,8 juta per bulan, 70,53 persen di antaranya mengalami penurunan

36 Mutia Fauzia, "Dampak Corona, Angka Kemiskinan Bisa Meningkat 3,78 Juta Orang," Kompas.Com, 2020.

37 Badan Pusat Statistik, Hasil Survei Sosial Demografi Dampak COVID-19 (Indonesia: Badan Pusat Statistik RI, 2020). 
pendapatan. Sementara masyarakat dengan pendapatan tinggi, di atas $\operatorname{Rp~7,2~juta~sebulan,~hanya~} 30,34$ persen saja yang merasakan penurunan pendapatan. ${ }^{38}$ Survei BPS soal Dampak COVID-19: 2,52\% Pekerja di PHK, Lulusan SMP Sulit WFH. Pandemi corona membuat status pekerja berubah. Ada yang terkena pemotongan gaji, dirumahkan, hingga PHK. Pertengahan April lalu, Kemnaker menyebut ada 2,8 juta pekerja di-PHK. Sementara akhir Mei, Kadin mencatat, total ada 6 juta pekerja yang kena PHK maupun dirumahkan. ${ }^{39}$

\section{UPAYA ISLAM DALAM MENGENTASKAN KEMISKINAN}

Dalam upaya pengetasan kemiskinan kebijakan pemerintah dapat mempengaruhi kemiskinan, baik langsung maupun tidak langsung. Kebijakan langsung adalah kebijakan dalam beberapa program yang khusus dibuat untuk mengurangi kemiskinan, jadi sasarannya adalah penduduk miskin. Sedangkan kebijakan tidak langsung adalah kebijakan ekonomi yang sasarannya bukan penduduk miskin, tetapi mempunyai pengaruh positif terhadap pengurangan kemiskinan, seperti kebijan membatasi impor suatu produk dengan tujuan industri dalam negri dapat tumbuh pesat, dan kebijakan moneter yang menurunkan suku bunga dengan tujuan investasi dalam dalam negri akan meningkat, selanjutnya

38 Badan Pusat Statistik.

39 Redaksi Kumparan, "Survei BPS Soal Dampak COVID-19: 2,52\% Pekerja di-PHK, Lulusan SMP Sulit WFH,” KumparanNEWS, 2020. 
akan menambah kesempatan kerja dan pada akhirnya akan mengurangi jumlah penduduk miskin. ${ }^{40}$

Menurut Bank Dunia, cara mengurangi tingkat kemiskinan adalah sebagai berikut: (1) Meningkatkan pertumbuha ekonomi dan padat karya sehingga menciptakan kesempatan kerja dan meningkatkan pendapatan masyarakat miskin, (2) Pengembangan sumber daya manausia lewat bidang pendidikan, kesehatan dan pemenuhan gizi sehingga mereka dapat memanfaatkan kesempatan-kesempatan yang diciptakan oleh pertumbuhan ekonmi, (3) Memberikan jaminan sosial kepada masyarakat miskin sehingga mereka memperoleh keuntungan-keuntungan dari pertumbuhan ekonomi dan pengembangan sumberdaya manusia akibat ketidakmampuan fisik, mental, bencana alam dan konflik sosial. ${ }^{41}$ Kemudian Bank dunia menambahkan tiga pilar untuk memerangi kemiskinan adalah pemberdayaan, keamanan dan kesempatan.

Berikut ini beberapa program unggulan pemerintah Indonesia dalam mengentaskan kemiskinan, antara lain sebagai berikut; (1) Menjaga stabilitas harga bahan kebutuhan pokok. (2) Mendorong pertumbuhan ekonomi yang berpihak pada rakyat miskin, (3) Menyempurnakan dan memperluas cakupan program pembangunan berbasis masyarakat, (4) Meningkatkan akses masyarakat miskin kepada pelayanan dasar, (5) Membangun dan Praktis, 215.

40 Tambunan, Perekonomian Indonesia Kajian Teoritis dan Analisis

41 Tambunan, 216. 
menyempurnakan sistem perlindungan sosial bagi masyarakat miskin. ${ }^{42}$

Islam sangat menentang kemiskinan dan berusaha keras untuk membendungnya serta mengawasi kemungkinan yang dapat menimbulkannya, untuk menyelamatkan akidah, akhlak, memelihara kehidupan rumah tangga, menjaga kestabilan dan ketentraman masyarakat dan untuk mewujudkan rasa persaudaraan dalam masyarakat. Berikut ini beberapa upaya yang ditawarkan Islam uantuk mengentaskan kemiskinan; ${ }^{43}$ Bekerja. Setiap orang dalam masyarakat Islam diharuskan bekerja. Karena bekerja merupakan senjata utama untuk memerangi kemiskinan, mencapai kekayaan dan kesejahteraan serta faktor utama dalam mencapai kemakmuran. (2) Mencukupi keluarga yang lemah. Sudah mendjadi dasar pokok dalam islam, bahwa setiap individu harus memerangi kemiskinan dengan bekerja dan berusaha. Dalam hal ini Islam berusaha mengentaskan kemiskinan dan berusaha menghindarkan mereka dari perbuaran yang hina, seperti mengemis dan meminta-minta. Maka dari itu islam memiliki konsep saling menjamin antar anggota keluarga dan masyarakat untuk meringankan penderitaan dan mengentaskan kemiskinan, seperti yang kuat membantu yang lemah dan yang kaya membantu yang miskin.

(3) Zakat. Islam tidak akan bersikap dingin dan menelantarkan mereka yang lemah (miskin). Karena mereka mempunyai hak tertentu dalam harta orang yang kaya dan

42 Ningrum, Kemiskinan dalam Bingkai Islam KeIndonesiaan, 27.

43 Al-Qordowi, Konsepsi Islam dalam Mengentaskan Kemiskinan, Ter. Umar Fanany, 52. 
mempunyai bagaian yang pasti didalamnya. Karena sasaran utama zakat adalah untuk mencukupi kebutuhan orang-orang miskin. (4) Dana bantuan perbendaharaan Islam dari berbagai sumber. Kekayaan Negara harus dikelola dan dimanfaatkan sebaik-baiknya untuk kepentingan rakyat bukan untuk kepentingan pribadi. Kekayaan ini dapat digunakan untuk meningkatkan kesejahteraan masyarakat dan sebagi sumber bantuan bagi masyarakat miskin ketika dana zakat sudah tidak mempu mencukupi lagi. (5) Keharusan memenuhi hak-hak selain zakat. Selain zakat ada hakhak material yang wajib dipenuhi oleh seorang muslim, yang mana sebagai sumber dana untuk membantu masyarakat miskin dalam mencapai kesejahteraan dan untuk menggurangi kemiskinan. Hakhak tersebut, diantaranya adalah: hak bertetangga, korban hari raya haji, kafarah, fidyah, al-hadyu (berkorban karena melakukan pelanggaran dalam ibadah haji), hak mencukupi fakir miskin. (6) Sedekah sukarela dan kebajikan individu. Untuk mengurangi tingkat kemiskinan, Islam berusaha membina pribadi yang luhur, dermawan dan murah hati. Pribadi yang luhur adalah pribadi yang suka member dan suka mendermakan lebih dari apa yang diwajibkan. Orang yang berbudi luhur akan mencintai orang lain, lebih dari dirinya sendiri, orang yang seperti ini penuh dengan kasih sayang dan cinta kasih kepada sesama. Dengan nilai-niali tersebut diharapkan mampu mengurangi tingkat kemiskinan dan masyarakat mampu mencapai kesejahteraan. 


\section{FILANTROPI ISLAM SOLUSI KEMISKINAN AKIBAT PANDEMI} COVID-19

Filantropi Islam (ZISWAF) merupakan ajaran yang melandasi bertumbuh kembangnya sebuah kekuatan sosial ekonomi umat yang memiliki beberapa dimensi yang kompleks. Jika dimensi tersebut dapat teraktualisasikan maka pembangunan masyarakat akan terwujud. ${ }^{44}$ Dimensi yang terkandung dalam filantropi Islam ini dapat dilihat melalui manfaat atau hikmah yang terkandung di dalamnya. Manfaat yang terkandung yait; (1) Dimensi spiritual, bertabahnya keimanan kepada Allah Swt. (2) Dimensi sosial, tercip-tanya masyarakat yang memiliki solidaritas tinggi, sehingga melahirkan kecintaan dan kepedulian terhadap sesama dan kekeluargaan antar umat akan semakin tampak. (3) Dimensi ekonomi, yaitu terciptanya masyarakat yang makmur sejahtera. Pada hakikatnya dengan terlaksananya filantropi Islam tersebut maka akan tercipta suatu masyarakat yang makmur, tenteram adil dan sejahtera.

Kemiskinan masih menjadi permasalahan utama di dunia, termasuk di Indonesia. Jumlah penduduk miskin di Indonesia pada September 2019 sebanyak 24,79 juta jiwa. Adapun tingkat kemiskinan sebesar 9,22\%. Untuk mengatasi masalah tersebut pemerintah menggelontorkan dana perlindungan sosial sebesar Rp 110 triliun untuk mengatasi dampak yang ditimbulkan dari pandemi Covid-19, terutama untuk penduduk miskin. Pemberian dana sosial tersebut telah diajarakan dalam Islam lewat prkatik

44 Sudirman, Zakat dalam Pusaran Arus Modernitas (Malang: UIN Malang Press, 2007), 1. 
ZISWAF. Maka salah satu solusi pengentasan kemiskinan yang tepat adalah dengan membangkitkan aktivitas sosial dan ekonomi dalam artian menerapkan filantropi Islam.

Filantropi Islam adalah kedermawanan sosial yang terprogram dan ditujukan untuk pengentasan masalah sosial (seperti kemiskinan). Filantropi Islam ada yang berorientasi pada pengentasan kemiskinan dalam jangka pendek dan jangka panjang, jangka pendek misalnya memberikan bantuan yang bersifat konsumtif sekali pakai habis. Adapun yang bersifat jangka panjang dengan memberikan bantuan yang bisa dimanfaatkan dalam waktu yang lama untuk meningkatkan pendapatan. Konsepnya tidak memberikan ikan tetapi memberi kail dan akses serta keadilan untuk memperoleh ekonomi.

Masalah kemiskinan tidak hanya terjadi di Indonesia, tetapi juga sangat dirasakan di seluruh negara-negara terutama dalam kasus ini yang terdampak oleh pandemi Covid-19. Kehidupan masyarkat semakin sulit karena wabah yang berkepanjangan. Filantropi Islam (ZISWAF ) dapat mengatasi masalah umat dan kemanusiaan terutama menjadi solusi atas masalah kemiskinan. Jadi, upaya pengentasan kemiskinan tersebut adalah dengan melalui pengembangan dan pengelolaan dana yang telah diperoleh dari ZISWAF dengan baik, dengan menitik beratkan pada pengeloaan dana secara produktif. Walaupun demikian ada sebagain dana yang diberikan kepada masyarakat yang bersifat konsumtif. 
Solusi yang dapat ditawarkan dalam beberapa model seperti, penyaluran bantuan langsung tunai yang berasal dari ZISWAF baik yang didapat dari lembaga unit-unit pengumpul zakat (BASNAS dan LAZIS) maupun langsung didapat dari masyarakat. Khusus untuk zakat, penyalurannya difokuskan terhadap mereka yang ekonominya melemah (masyarakat miskin) akibat terdampak Covid-19. Untuk itu perlu dilakukan sosialiasi dan kampanye tetang pentingnya ZISWAF dalam menghadapi permasalahan kemiskinan terutama yang disebabkan akibat adanya Covid-19. Kampanye dan sosialisasi dapat dilakukan dengan berbagai cara melalui media sosial (online) maupun media cetak (offline). Dengan demikian, diharapkan timbul kepekaan dan pemahaman masyarakat terhadap pentingnya ZISWAF dalam menghadapi permasalahan ekonomi selama masa pandemi ini. Dana tersebut juga dapat dimanfaatkan untuk menunjang pencegahan Covid-19 seperti pembangunan dan pengadaan fasilitas penunjang pencegahan Covid-19 seperti APD (alat pelindung diri), rumah isolasi, rumah sakit darurat, alat medis, dan segala keperluan lainnya yang bersangkutan dengan pencegahan Covid-19.

Oleh karena itu diperlukannya sosialisai skema pengelolaan filantropi Islam kepada masyarakat bahwa pengelolaan ZISWAF tidak hanya berkutat pada ibadah yang bersifat formal, namun juga bisa dimanfaatkan untuk segala aktifitas yang bersifat kebaikan bersama (ibadah yang bersifat sosial), salah satunya adalah pengentasan kemiskinan akibat pandemi Covid-19. Dana ZISWAF jika dikelola dengan manajemen yang baik dan bersifat 
produktif (investasi) maka dapat diputar untuk kegiatan yang bersifat jangka panjang, sehingga dana tersebut tidak akan habis sampai kapanpun bahkan mampu berkembang sehingga pemanfaatanya akan semakin besar dan luas. Dana ZISWAF yang bersifat konsumtif akan meningkatkan permintaan dan daya beli masyarkat, sedangkan dana yang bersifat produktif akan mampu meningkatkan kegiatan investasi dan produktifitas perusahaan (kegiatan bisnis) sehingga hal tersebut mampu meningkatkan penggunaan tenaga kerja (mengurangi pengangguran) dan pada akhirnya meningkatkan kesejahteraan masyarakat sehingga kemiskinan semakin berkurang. Dengan upaya tersebut diharapkan dapat meningkatkan kembali aggregate demand dan aggregate supply ke kanan (dalam kurva demand and supply) diikuti dengan pembangunan pasar daring yang fokus kepada sektor ekonomi riil yang mempertemukan permintaan dan penawaran, sehingga surplus ekonomi terbentuk kembali dan membantu percepatan pemulihan ekonomi. Penjelasan tersebut membuktikan bahwa filantropi Islam mampu menjadi solusi atas masalah kemiskinan. Penjelasan tersebut didukung oleh hasil analisa dan penelitian yang dilakukan oleh beberapa peneliti dan tokoh terdahulu. 454647

45 Azwar, "Solusi Ekonomi dan Keuangan Islam Saat Pandemi Covid-19." 46 Imron Hadi Tamim, "Peran Filantropi dalam Pengentasan Kemiskinan di dalam Komunitas Lokal," The Sociology of Islam 1, no. 1 (2011).

${ }^{47}$ Feri Irawan, "Peran Filantropi Zakat dalam Pengentasan Kemiskinan di Indonesia,” Tafáqquh: Jurnal Penelitian dan Kajian Keislaman 7, no. 2 (2019). 


\section{KESIMPULAN}

Filantropi Islam adalah kedermawanan sosial yang terprogram dan ditujukan untuk pengentasan masalah ekonomi seperti kemiskinan. Masalah kemiskinan tidak hanya terjadi di Indonesia, tetapi juga terjadi diseluruh negara terutama dalam kasus ini adalah negara-negara yang terdampak oleh pandemi Covid-19. Kehidupan masyarkat yang semakin sulit karena wabah yang berkepanjangan. Filantropi Islam (ZISWAF) mampu solusi bagi masyarakat atas maslah kemiskinan yang terjadi. Upaya pengentasan kemiskinan yang dapat dilakukan adalah dengan melalui pengembangan dan pengelolaan dana yang telah diperoleh dari ZISWAF dengan baik, dengan menitik beratkan pada pengeloaan dana secara produktif.

Walaupun demikian ada sebagain dana yang diberikan kepada masyarakat yang bersifat konsumtif. Dana ZISWAF jika dikelola dengan manajemen yang baik dan bersifat produktif (investasi) maka dapat diputar untuk kegiatan yang bersifat jangka panjang, sehingga dana tersebut tidak akan habis sampai kapanpun bahkan mampu berkembang sehingga pemanfaatanya akan semakin besar dan luas. Dana ZISWAF yang bersifat konsumtif akan meningkatkan permintaan dan daya beli masyarkat, sedangkan dana yang bersifat produktif akan mampu meningkatkan kegiatan investasi dan produktifitas perusahaan (kegiatan bisnis) sehingga hal tersebut mampu meningkatkan penggunaan tenaga kerja penuh (mengurangi pengangguran) dan pada akhirnya meningkatkan kesejahteraan masyarakat sehingga kemiskinan semakin berkurang. Penjelasan tersebut membuktikan 
bahwa filantropi Islam mampu menjadi solusi atas masalah kemiskinan.

\section{DAFTAR PUSTAKA}

Ahmadi, Abu. Ilmu Sosial Dasar. Jakarta: PT Renika Cipta, 1991.

Al-Qordowi, Muhammad Yusuf. Konsepsi Islam dalam Mengentaskan Kemiskinan, Ter. Umar Fanany. PT. Bina Ilmu Ofset: PT.Bina Ilmu Ofset, 1996.

Ash-Shiddieqy, Hasbi. Pedoman Zakat. Jakarta: Bulan Bintang, 1984.

Azwar. "Solusi Ekonomi dan Keuangan Islam Saat Pandemi COVID19." Kementerian Keuangan RI, 2020.

Badan Pusat Statistik. "Ekonomi Indonesia Triwulan I 2020 Tumbuh 2,97 Persen." BPS. 2020.

-_- Hasil Survei Sosial Demografi Dampak COVID-19. Indonesia: Badan Pusat Statistik RI, 2020.

_-_. "Kemiskinan Dan Ketimpangan." www.bps.go.id, n.d.

Barbara, Ibrahim. From Charity to Social Change: Trends in Arab Philanthropy. Cairo: American University in Cairo Press, 2008.

Baridzi, Achmad al-Nidzami. "Solusi Ekonomi dan Keuangan Islam dalam Menghadapi Pandemi Covid-19." Kompasiana, 2020.

Fauzia, Mutia. "Dampak Corona, Angka Kemiskinan Bisa Meningkat 3,78 Juta Orang." Kompas.Com, 2020.

Irawan, Feri. "Peran Filantropi Zakat dalam Pengentasan Kemiskinan di Indonesia." Tafáqquh: Jurnal Penelitian dan Kajian Keislaman 7, no. 2 (2019).

K, Anheier Helmut, and List Regina A. A Dictionary of Civil Society, Philanthropy and the Non-Profit Sector. New York: Routledge, 2005.

Koentjaraningrat. Kebudayaan, Mentalitet dan Pembangunan. Jakarta: Gramedia, 1983.

Kuncoro, Mudrajad. Ekonomi Pembangunan Teori, Masalah dan 
Kebijakan. Yogyakarta: UPP-AMP YKPN, 1997.

Linge, Abdiansyah. "Filantropi Islam Sebagai Instrumen Keadilan Ekonomi." Jurnal Perspektif Ekonomi Darussalam 1, no. 2 (2015).

Mahfud, Rois. Al-Islam. Jakarta: Erlangga, 2011.

Mardani. Fiqih Mu'amalah. Jakarta: Kencana Prenada Media Group, 2012.

Ningrum, Ririn Tri Puspita. Kemiskinan dalam Bingkai Islam KeIndonesiaan. Yogyakarta: Interpena, 2013.

Prasetia, Andhika. "Prediksi Pemerintah Pasien Corona Akan Bertambah.” DetikNews, 2020.

Purwanto, Erwan Agus. "Mengkaji Potensi Usaha Kecil dan Menengah untuk Pembuatan Kebijakan Anti Kemiskinan di Indonesia." Jurnal Ilmu Sosial dan Ilmu Politik 10, no. 3 (2007).

Redaksi Kumparan. "Survei BPS Soal Dampak Covid-19: 2,52\% Pekerja Di-PHK, Lulusan SMP Sulit WFH." KumparanNEWS, 2020.

Rejekiningsih, Tri Wahyu. "Identifikasi Faktor Penyebab Kemiskinan di Kota Semarang dari Dimensi Kultural." Jurnal Ekonomi Pembanguna 12, no. 1 (2011).

Ridwan, Muhammad. Manajemen Baitul Maal da Tanwil. Yogyakarta: UII Press, 2011.

Rizal, Fitra. "Wakaf Non Muslim dan Wakaf Uang Menurut Pandangan Wahbah Zuhaili." Al-Intaj: Jurnal Ekonomi dan Perbankan Syariah 5, no. 2 (September 9, 2019): 176. https://doi.org/10.29300/aij.v5i2.2059.

Sudirman. Zakat Dalam Pusaran Arus Modernitas. Malang: UIN Malang Press, 2007.

Sukirno, Sadono. Makroekonomi: Teori Pengantar. Jakarta: PT. Rajagrafindo Persada, 2011.

Tambunan, Tulus T.H. Perekonomian Indonesia Kajian Teoritis dan Analisis Praktis. Bogor: Ghalia Indonesia, 2012.

Tamim, Imron Hadi. "Peran Filantropi Dalam Pengentasan Kemiskinan di dalam Komunitas Lokal." The Sociology of Islam 1, no. 1 (2011). 
The World Bank. Making the New Indonesia Work for the Poor. Washigton, DC: The World Bank, 2006.

Todoro, Micheal P. Pembangunan Ekonomi di Dunia Ketiga, Ter. Haris Munandar. Jakarta: PT. Gelora Aksara Pratama, 1998.

Uyun, Qurratul. "Zakat, Infaq, Shadaqah, dan Wakaf Sebagai Konfigurasi Filantropi Islam." Jurnal Islamuna 2, no. 2 (2015).

Yunus, Nur Rohim, and Annissa Rezki. "Kebijakan Pemberlakuan Lockdown Sebagai Antisipasi Penyebaran Corona Virus Covid19." SALAM; Jurnal Sosial \& Budaya Syar-I 7, no. 3 (2020).

Zuhdi. Studi Islam. Jakarta: PT. Rajagrafindo Persada, 1993. 